\title{
TREATY BETWEEN THE GOVERNMENT OF THE REPUBLIC OF INDIA AND THE GOVERNMENT OF THE PEOPLE'S REPUBLIC OF BANGLADESH ON SHARING OF THE GANGA/GANGES WATERS AT FARAKKA
}

New Delhi, 12 December 1996

Determined to promote and strengthen their relations of friendship and good neighbourliness,

Being desirous of sharing by mutual agreement the waters of the international rivers flowing through the territories of the two countries and of making the optimum utilisation of the water resources of their region in the fields of flood management, irrigation, river basin development and generation of hydro-power for the mutual benefit of the peoples of the two countries,

Being desirous of finding a fair and just solution without affecting the rights and entitlements of either country other than those covered by this Treaty, or establishing any general principles of law or precedent,

Have agreed as follows:

\section{Article 1}

The quantum of waters agreed to be released by India to Bangladesh will be at Farakka.

\section{Article 2}

(i) The sharing between India and Bangladesh of the Ganga/Ganges waters at Farakka by ten day periods from the 1st January to the 31st May every year will be with reference to the formula at Annexure I and an indicative schedule giving the implications of the sharing arrangement under Annexure I is at Annexure II.

(ii) The indicative schedule at Annexure II, as referred to in sub para (i) above, is based on 40 years (1949-1988) 10-day period average availability of water at Farakka. Every effort would be made by the upper riparian to protect flows of water at Farakka as in the 40-years average availability as mentioned above.

(iii) In the event flow at Farakka falls below 50,000 cusecs in any 10-day period, the two governments will enter into immediate consultations to make adjustments on an emergency basis, in accordance with the principles of equity, fair play and no harm to either party.

\section{Article 3}

The waters released to Bangladesh at Farakka under Article I shall not be reduced below Farakka except for reasonable uses of waters, not exceeding 200 cusecs, by India between Farakka and the point on the Ganga/Ganges where both its banks are in Bangladesh.

\section{Article 4}


A Committee consisting of representatives nominated by the two Governments in equal numbers (hereinafter called the Joint Committee) shall be constituted following the signing of this Treaty. The Joint Committee shall set up suitable teams at Farakka and Hardinge Bridge to observe and record at Farakka the daily flows below Farakka Barrage, in the Feeder Canal, and at the Navigation Lock, as well as at the Hardinge Bridge.

\section{Article 5}

The Joint Committee shall decide its own procedure and method of functioning.

\section{Article 6}

The Joint Committee shall submit to the two Governments all data collected by it and shall also submit a yearly report to both the Governments. Following submission of the reports the two Governments will meet at appropriate levels to decide upon such further actions as may be needed.

\section{Article 7}

The Joint Committee shall be responsible for implementing the arrangements contained in this Treaty and examining any difficulty arising out of the implementation of the above arrangements and of the operation of Farakka Barrage. Any difference or dispute arising in this regard, if not resolved by the Joint Committee, shall be referred to the Indo-Bangladesh Joint Rivers Commission. If the difference or dispute still remains unresolved, it shall be referred to the two Governments which shall meet urgently at the appropriate level to resolve it by mutual discussion.

\section{Article 8}

The two Governments recognise the need to cooperate with each other in finding a solution to the long-term problem of augmenting the flows of the Ganga/Ganges during the dry season.

\section{Article 9}

Guided by the principles of equity, fairness and no harm to either party, both the Governments agree to conclude water sharing Treaties/Agreements with regard to other common rivers.

\section{Article 10}

The sharing arrangement under this Treaty shall be reviewed by the two Governments at five years' interval or earlier, as required by either party and needed adjustments, based on principles of equity, fairness, and no harm to either party made thereto, if necessary. It would be open to either party to seek the first review after two years to assess the impact and working of the sharing arrangements as contained in this Treaty.

\section{Article 11}

For the period of this Treaty, in the absence of mutual agreement on adjustments following reviews as mentioned in Article X, India shall release downstream of Farakka Barrage, water at a rate not less than $90 \%$ (ninety per cent) of Bangladesh's share according to the formula referred to in Article II, until such time as mutually agreed flows are decided upon. 


\section{Article 12}

This Treaty shall enter into force upon signature and shall remain in force for a period of thirty years and it shall be renewable on the basis of mutual consent.

DONE at New Delhi 12th December, 1996 in Hindi, Bangla and English languages. In the event of any conflict between the texts, the English text shall prevail.

\section{ANNEXURE I}

Availability at

Farakka

70,000 cusecs or less

$70,000-75,000$ cusecs

75,000 cusecs

or more
Share of India

$50 \%$

Balance of flow

40,000 cusecs

\section{Share of}

Bangladesh

$50 \%$

35,000 cusecs

Balance of flow

Subject to the condition that India and Bangladesh each shall receive guaranteed 35,000 cusecs of water in alternate three 10-day periods during the period March 1 to May 10.

[Annexure II is not reproduced] 